\title{
Pengaruh Subjective Norm Terhadap Intensi Berwiratani Pada Mahasiswa Pertanian Di Aceh
}

\author{
Ridha Rizki Novanda \\ Fakultas Pertanian, Universitas Bengkulu, Indonesia \\ e-mail : rrizkin@unib.ac.id
}

\begin{abstract}
The majority of human resources in the agricultural sector are elderly. The low contribution of youth is due to the high risk of youth in the agricultural sector. The agricultural sector needs young people who are creative and innovative and are oriented towards entrepreneurial activities. So it is essential to analyze the influence of the Subjective Norm on the spiritual intentions of agricultural students in Aceh. The study was conducted on agricultural students in Aceh with 150 respondents. Data analysis was performed descriptively and using ordinal regression. All variables of the Subjective Norm have a significant influence on the intentions of agricultural students in engaging. Subjective Norm originating from parents, family, business teams, and business consultants influences intention.
\end{abstract}

Keywords: Intention, student, subjective norm

\section{Abstrak}

Sumberdaya manusia disektor pertanian mayoritas merupakan sumberdaya manusia dengan usia lanjut. Rendahnya kotribusi pemuda dikarenakan tingginya risiko disektor pertanian. Sektor pertanian sangat membutuhkan anak muda yang kreatif dan inovatif serta berorientasi kepada kegiatan kewirausahaan. Sehingga penting untuk menganalisis pengaruh Subjective Norm terhadap intensi berwiratani bagi mahasiswa pertanian yang berada di Aceh. Penelitian dilakukan pada mahasiswa pertanian yang berada di Aceh dengan jumlah responden sebanyak 150 orang. Analisis data dilakukan secara deskriptif dan menggunakan regresi ordinal. Keseluruhan variable dari Subjective Norm memiliki pengaruh signifikan terhadap intensi mahasiswa pertanian dalam berwiratani. Subjective Norm yang berasal dari Orang tua, keluarga, tim bisnis, dan konsultan bisnis berpengaruh terhadap Intensi.

Kata Kunci: Intensi, mahasiswa, subjective norm

\section{PENDAHULUAN}

Sektor pertanian merupakan sektor yang memiliki pengaruh besar terhadap Indonesia. Indonesia sebagai Negara agraris berperan penting untukmenghasilkan sumber daya alam berkualitas dan dapat memberikan nilai tambah untuk peningkatan pendapatan masyarakat. Akan tetapi, sektor petanian merupakan sektor yang ditinggalkan oleh pemuda. Saat ini, sumberdaya manusia disektor pertanian mayoritas merupakan sumberdaya manusia dengan usia lanjut..
Rendahnya kotribusi pemuda dikarenakan tingginya risiko disektor pertanian. Sehingga krisis pemuda disektor pertanian sangat dirasakan. Selain itu, usaha disektor pertanian membutuhkan modal yang besar (Boateng, Polytechnic, Boateng, Polytechnic, \& Bampoe, 2014; Panday, 2015). Sehingga pemuda lebih memilih sektor pertanian dibandingkan pertanian.

Begitupun pemuda yang berasal dari latarbelakang pendidikan pertanian. Sebagian besar hijrah dari sektor pertanian 
ke non pertanian. Menurut Parcell (2003), bahwa sarjana pertanian lebih memilih sektor non pertanian dibandingkan pertanian sebagai pilihan karir.

Menurut Pambudy (2005), sektor pertanian sangat membutuhkan anak muda yang kreatif dan inovatif serta berorientasi kepada kegiatan kewirausahaan. Dimana pemuda sebagai wiratani dapat mengembangkan sektor pertanian melalui kegiatan menghasilkan pendapatan.

Dalam rangka meningkatkan niat berwirausaha, kurikulum di perguruan tinggi harus memastikan mahasiswa mendpatkan pendidikan kewirausahaan. Menurut Susilaningsih (1997), pendidikan kewirausahaan umumnya berisi materi dan aktivitas yang berhubungan dengan membangun sikap mental kewirausahaan, melatih keterampilan berkomunikasi, membangun jejaring dan menyusun rencana bisnis yang berorientasi pada keuntungan.

Fakultas pertanian di Aceh juga mengadopsi kurikulum kewirausahaan bagi mahasiswa pertanian di aceh tanpa terkecuali. Sebagai daerah paling miskin di Sumatera, Aceh optimis dapat maju disektor pertania khususnya komoditas kopi yang memiliki khas tertentu sebagai kopi paling banyak diminati di Indonesia. Berkaitan dengan hal tersebut, untuk meningkatkan status provinsi maka penting agar mahasiswa di aceh memiliki niat wiratani yang ditanamkan sejak masa perkuliahan.

Intensi berwiratani merupakan kecenderungan hati yang sangat tinggi untuk menjadi seorang wiratani. Sehingga penting bagi mahasiwa pertanian memiliki ontensi untuk menjadi wiratani. Berdasarkan hasil penelitian (Ridha \& Wahyu, 2017) Subjective Norm atau norma subjektif sangat berpengaruh terhadap intensi berwiratani bagi pemuda Indonesia. Subjective Norm merupakan pandangan seseorang terhadap kepercayaankepercayaan orang terdekat yang akan mempengaruhi niat untuk menjadi atau tidak menjadi wiratani.

Sehingga penting untuk menganalisis pengaruh Subjective Norm terhadap intensi berwiratani bagi mahasiswa pertanian yang berada di aceh. Pandangan mahasiswa terhadap kepercayaan-kepercayaan orang terdekat yaitu: (1) Orang tua, (2) keluarga, (3) Tim bisnis, dan (4) Konsultan bisnis terhadap intensi berwiratani.

\section{METODE}

\subsection{Pengumpulan dan Analisis Data}

Penelitian dilakukan pada mahasiswa pertanian yang berada di Aceh. Aceh dipilih sebagai salah satu provinsi paling miskin dan tertinggal yang berada di kelupauan Sumatera. Jumlah responden yang dipilih ialah sebanyak 150 orang. Data yang dibutuhkan merupakan data primer dan sekunder yang disebar menggunakan kuesioner online ke sosial media ikatan mahasiswa se-Provinsi Aceh.

Analisis data dilakukan secara deskriptif dan menggunakan regresi ordinal untuk melihat pengaruh subjectif norm terhadap Intensi wirausahatani mahasiswa pertanian di provinsi Aceh. Subjectif norm persepsi atau pandangan seseorang terhadap kepercayaan-kepercayaan orang lain yang akan mempengaruhi niat untuk melakukan atau tidak melakukan perilaku yang sedang dipertimbangkan. Dalam 
penelitian ini Subjectif norm (SN) ditujukan untuk memenuhi harapan Orang tua (SN1), teman dekat (SN2), Teman satu tim (SN3), dan Konsultan Bisnis (SN4).

Regresi ordinal merupakan salah satu analisis regresi yang digunakan untuk menganalisa hubungan antara variabel respon dengan variabel prediktor, dimana variabel respon bersifat polikotomus dengan skala ordinal. tahapan regresi ordinal yaitu digunakan dalam penelitian ini ialah hanya dari tahap Model Fitting Information, Goodness of Fit, Pseudo R-Square hingga Hasil uji hipotesis parsial (Ryan, 1997).

a. Model Fitting Information (Uji Keberartian Model)

Menjelaskan pengaruh masuknya variabel independent ke model final yang menyebabkan naik/turunnya nilai final model. Kondisi ini menghasilkan chi square yang diharapkan dapat signifikan dengan model chi square yang signifikasinya lebih kurang dari nilai alfa atau model layak untuk digunakan (Ryan, 1997).

b. Goodness of Fit (Uji Kebaikan Model)

Goodness of Fit menunjukkan uji kesesuaian model dengan data dimana signifikasi harus lebih besar dari nilai alfa. Hal ini berarti model sesuai dengan data empiris atau model layak digunakan. pada tahap goodness of fit dilakukan dengan uji deviance. Deviance didasarkan pada kriteria

\section{HASIL DAN PEMBAHASAN}

\subsection{Gambaran Umum Responden}

Responden pada penelitian ini ialah mahasiswa dari berbagai perguruan tinggi di Aceh yang memiliki konsentrasi pendidikan pertanian. Mayoritas responden ialah rasio likelihood untuk membandingkan model current (model tanpa peubah penjelas) dengan model penuh (model dengan peubah penjelas). Statistik uji Deviance didefinisikan dengan persamaan :

$$
\begin{gathered}
D=-2 \sum_{i=1}^{n}\left[y_{i} \ln \left(\frac{\hat{\pi}_{i}}{y_{i}}\right)+\left(1-y_{i}\right) \ln \left(\frac{1-\hat{\pi}_{i}}{1-y_{i}}\right)\right] \\
\hat{\pi}_{i}=\frac{\exp \left(g\left(x_{i}\right)\right)}{1+\left(g\left(x_{i}\right)\right)} \\
g\left(x_{1}\right)=\beta_{0}+\beta_{1} x_{n}+\cdots+\beta_{p} x_{i p}, i=1,2, \ldots, n
\end{gathered}
$$

c. Koefisien Determinasi Model

Pseudo R-Square menunjukkan bahwa seberapa besar variabel bebas mampu menjelaskan variabel independen. Nilai ini seperti halnya koefesien determinasi pada regresi.

d. Hasil uji hipotesis parsial

Digunakan untuk melihat hasil pengujian hipotesis masing-masing variabel. Uji parsial digunakan sebagai uji akhir dalam penelitian ini karena ingin pengaruh masingmasing variabel independent terhadap variabel dependentnya dan tidak dilanjutkan kepada odds ratio.

Skala pengukuran variabel yang digunakan dalam peneltian ini ialah ordinal. Skala ordinal didapatkan dari pengukuran indikator-indikator menggunakan skala likert 1-5 yang dituangkan melalui kuesioner penelitian. Sehingga analisis data dilakukan menggunakan regresi ordinal.

berasal dari angkatan lebih kurang dari 2015 dengan persentase $95 \%$ dari total responden. Responden mayoritas berasal dari jurusan agroteknologi dengan persentase sebesar $45 \%$ disusul oleh agribisnis sebesar $35 \%$. Suku responden paling banyak ialah suku aceh dengan persentase sebesar 55\%. Sementara 
pekerjaan orang tua mayoritas yaitu petani sebesar $67 \%$.

Tabel 1. Gambaran umum responden

\begin{tabular}{|c|c|c|}
\hline Uraian & Jumlah & $\%$ \\
\hline \multicolumn{3}{|l|}{ Angkatan } \\
\hline $2015 \geq$ & 144 & $96.00 \%$ \\
\hline 2012-2014 & 2 & $1.33 \%$ \\
\hline $2011 \leq$ & 4 & $2.67 \%$ \\
\hline \multicolumn{3}{|l|}{ Jurusan } \\
\hline Agribisnis & 52 & $35 \%$ \\
\hline IImu Hama Penyakit & 3 & $2 \%$ \\
\hline Agroteknologi & 68 & $45 \%$ \\
\hline Tenologi Hasil Pertanian & 12 & $8 \%$ \\
\hline Peternakan & 15 & $10 \%$ \\
\hline \multicolumn{3}{|l|}{ Suku } \\
\hline Batak & 17 & $11 \%$ \\
\hline Pakpak & 4 & $3 \%$ \\
\hline Aceh & 82 & $55 \%$ \\
\hline Melayu & 10 & $7 \%$ \\
\hline Bugis & 3 & $2 \%$ \\
\hline Sunda & 8 & $5 \%$ \\
\hline Jawa & 20 & $13 \%$ \\
\hline Anak Jamee & 6 & $4 \%$ \\
\hline \multicolumn{3}{|l|}{ Pekerjaan Orang tua } \\
\hline Petani & 101 & $67 \%$ \\
\hline PNS & 25 & $17 \%$ \\
\hline Tidak bekerja & 13 & $9 \%$ \\
\hline Wirausaha & 11 & $7 \%$ \\
\hline
\end{tabular}

\subsection{Hasil Uji Regresi Ordinal}

\section{a. Model Fitting Information}

Model Fitting Information -2log Likelihood menerangkan bahwa tanpa memasukkan variabel independen (intercept only) memiliki nilai 127,237. Namun dengan memasukkan variabel independen ke model (final) terjadi penurunan nilai menjadi 69,410 . Perubahan nilai ini diakibatkan oleh nilai chi-square yaitu 57,827 dan signifikan pada taraf nyata $5 \%$ (sig.0.00).

Tabel 2. Model Fitting Information

\begin{tabular}{|c|c|c|c|c|}
\hline Model & $\begin{array}{c}-2 \text { Log } \\
\text { Likelihood }\end{array}$ & $\begin{array}{c}\text { Chi- } \\
\text { Square }\end{array}$ & $d f$ & Sig. \\
\hline $\begin{array}{l}\text { Intercept } \\
\text { Only }\end{array}$ & 127.237 & & & \\
\hline Final & 69.410 & 57.827 & 9 & .000 \\
\hline
\end{tabular}

\section{b. Goodness of Fit}

Goodness of Fit menunjukkan uji kesesuaian model dengan data yang digunakan. Pada uji goodness of fit terlihat Sig yang berbeda antara uji pearson dan deviance. Deviance menunjukkan nilai Sig sebesar 0.889 lebih besar dari nilai alpha. Sehingga dapat disimpulkan bahwa model sudah fit.

Tabel 3. Goodness of Fit

\begin{tabular}{lcccc}
\hline & $\begin{array}{c}\text { Chi- } \\
\text { Square }\end{array}$ & df & & Sig. \\
\hline Pearson & 148.828 & 66 & .000 \\
Deviance & 52.358 & & 66 & .889 \\
\hline
\end{tabular}

C. Koefisien Determinasi Model

Pseudo R-Square menunjukkan bahwa seberapa besar variabel bebas mampu menjelaskan variabel independen. Nilai Cox and Snell sebesar 0.320 menunjukkan bahwa variabel $X$ dapat menjelaskan variabel $Y$ sebesar 32\%. 68\% lainnya dijelaskan oleh variabel lain diluar model.

Tabel 4. Pseudo R-Square

\begin{tabular}{lc}
\hline \multicolumn{2}{c}{ Pseudo R-Square } \\
\hline Cox and Snell & .272 \\
Nagelkerke & .305 \\
McFadden & .143 \\
\hline
\end{tabular}

d. Hasil uji hipotesis parsial

Dari output parameter pada table 5 estimates diatas terlihat bahwa yang signifikan adalah $\mathrm{SN} 1=4, \mathrm{SN} 3=4, \mathrm{SN} 4=3$, $\mathrm{SN} 4=4$. 
Tabel 5. Uji Hipotesis Parsial

\begin{tabular}{|c|c|c|c|c|c|c|c|c|}
\hline & & \multirow{2}{*}{ Estimate } & \multirow{2}{*}{ Std. Error } & \multirow{2}{*}{ Wald } & \multirow{2}{*}{ df } & \multirow{2}{*}{ Sig. } & \multicolumn{2}{|c|}{$\begin{array}{c}95 \% \text { Confidence } \\
\text { Interval }\end{array}$} \\
\hline & & & & & & & $\begin{array}{l}\text { Lower } \\
\text { Bound }\end{array}$ & $\begin{array}{l}\text { Upper } \\
\text { Bound }\end{array}$ \\
\hline \multirow[t]{3}{*}{ Threshold } & {$[l=2.00]$} & -6.734 & 1.290 & 27.246 & 1 & .000 & -9.263 & -4.205 \\
\hline & {$[I=3.00]$} & -4.056 & .658 & 37.985 & 1 & .000 & -5.346 & -2.766 \\
\hline & {$[I=4.00]$} & -1.599 & .358 & 19.989 & 1 & .000 & -2.300 & -0.898 \\
\hline \multirow[t]{13}{*}{ Location } & [SN1=3] & -.420 & .689 & .004 & 1 & .951 & -1.392 & 1.308 \\
\hline & {$[\mathrm{SN} 1=4]$} & -1.070 & .504 & 4.513 & 1 & .034 & -2.057 & -.083 \\
\hline & {$[\mathrm{SN} 1=5]$} & $0^{a}$ & & & 0 & & . & . \\
\hline & [SN2=3] & -22.580 & 1.547 & 1.547 & 1 & .996 & -0.996 & -.886 \\
\hline & {$[\mathrm{SN} 2=4]$} & .307 & .539 & .539 & 1 & .570 & -.750 & 1.364 \\
\hline & [SN2=5] & $0^{a}$ & & & 0 & & . & . \\
\hline & [SN3=3] & 19.844 & .606 & .000 & 1 & .997 & -.992 & 9963.937 \\
\hline & {$[\mathrm{SN} 3=4]$} & 1.623 & .572 & 8.055 & 1 & .005 & -.502 & 2.744 \\
\hline & {$[\mathrm{SN} 3=5]$} & $0^{a}$ & & . & 0 & . & . & \\
\hline & [SN4=1] & 18.000 & 0.000 & . & 1 & . & 18.000 & 18.000 \\
\hline & {$[\mathrm{SN} 4=3]$} & -1.307 & .637 & 4.213 & 1 & .040 & -2.555 & -.059 \\
\hline & {$[\mathrm{SN} 4=4]$} & -1.819 & .557 & 10.648 & 1 & .001 & -2.912 & -.726 \\
\hline & [SN4=5] & $0^{a}$ & & & 0 & & & \\
\hline
\end{tabular}

Beberapa model yang terbentuk adalah sebagai berikut :

$\ln \frac{P(Y \leq 2)}{(Y>2)}=-6.734-1.070 S N 1+$ 1.623 SN3 - 1.307 SN 4

$\ln \frac{P(Y \leq 3)}{(Y>3)}=-4.056-1.070 S N 1+$

1.623 SN3 - 1.307 SN4

$\ln \frac{P(Y \leq 4)}{(Y>4)}=-1.599-1.070 S N 1+$

1.623 SN3 - 1.307 SN4

$\ln \frac{P(Y \leq 2)}{(Y>2)}=-6.734-1.070 S N 1+$

1.623 SN3 - 1.819 SN4

$\ln \frac{P(Y \leq 4)}{(Y>4)}=-1.599-1.070$ SN $1+$

1.623 SN3 -1.819 SN 4

\subsection{Pengaruh Subjective Norm Terhadap} Intensi Berwiratani Pada Mahasiswa Pertanian di Aceh

Berdasarkan hasil uji menggunakan regresi ordinal (Tabel 4), didapatkan bahwa subjective norm memiliki pengaruh terhadap intensi wiratani. Pertama, Subjective Norm yang berasal dari Orang tua berpengaruh signifikan dengan nilai signifikasi sebesar 0,034. Kedua, Subjective Norm yang berasal dari keluarga berpengaruh signifikan dengan nilai signifikasi sebesar 0,000. Ketiga, Subjective Norm yang berasal dari Teman dalam tim Bisnis berpengaruh signifikan dengan nilai signifikasi sebesar 0,005 . Keempat, Subjective Norm yang berasal dari konsultan bisnis berpengaruh signifikan dengan nilai signifikasi sebesar 0,001 .

\subsubsection{Subjective Norm yang berasal dari} Orang tua berpengaruh terhadap Intensi

Subjectif norm persepsi atau pandangan seseorang terhadap kepercayaankepercayaan orang tua yang akan mempengaruhi niat untuk melakukan atau tidak melakukan perilaku yang sedang dipertimbangkan. Orang tua sangat 
berpengaruh besar terhadap intesi wiratani mahasiswa pertanian di Aceh. Kecederungan hati yang sangat tinggi untuk menjadi wiratani sangat ditentukan oleh sikap orang tua dalam menerima itu (Ridha \& Wahyu, 2017). Pilihan karir dari anak sangat ditentukan oleh dukungan dan pola piker dari orang tuanya (Candra \& Sawitri, 2017; Palos, 2016). Semakin positif persepsi seseorang terhadap dukungan orangtua maka semakin rendah kesulitan yang dirasakan dalam mengambil keputusan karir (Islamadina \& Yulianti, 2005).

Harapan orang tua terhadap anaknya yang mengenyam pendidikan ialah sukses. Sejalan dengan hal tersebut, mayoritas pandangan orang tua responden menyatakan bahwa bekerja merupakan kesuksesan setelah mereka lulus kuliah. Sementara wiratani tidak memiliki kepastian akan kesuksesan sehingga sangat berpengaruh terhadap keputusan responden untuk melanjutkan/memulai bisnisnya.

Berbeda dengan responden yang memiliki orang tua dengan latar belakang wirausaha. Orang tua dengan latar belakang tersebut sangat mendukung anaknya memilih karir sebagai wiratani. Sehingga intensi untuk berwirausaha disektor pertanian sangat tinggi akibat dukungan tersebut. Keinginan orang tua ialah untuk anaknya menjadi sukses.

\subsubsection{Subjective Norm yang berasal dari} keluarga berpengaruh terhadap Intensi

Subjectif norm persepsi atau pandangan seseorang terhadap kepercayaankepercayaan keluarga yang akan mempengaruhi niat untuk melakukan atau tidak melakukan perilaku yang sedang dipertimbangkan. Keluarga ialah ikatan seseorang kepada orang lain akibat hubungan sedarah, pernikahan, atau hubungan akibat adopsi. Lingkungan keluarga sangat berpengaruh dengan intensi wiratani bagi mahasiswa pertanian. Lingkungan keluarga sangat menentukan karir dari mahasiswa. Sehingga kondisi keluarga yang memiliki dukungan terhadap pilihan karir menjadi witausaha di sektor pertanian sangat menentukan. Sejalan dengan penelitian yang dilakukan Setiabudi (2019), menunjukkan bahwa dukungan keluarga dan kepribadian wirausaha berpengaruh signifikan positif terhadap niat berwirausaha mahasiswa.

\subsubsection{Subjective Norm yang berasal dari tim bisnis berpengaruh terhadap Intensi}

Subjectif norm persepsi atau pandangan seseorang terhadap kepercayaankepercayaan tim bisnis yang akan mempengaruhi niat untuk melakukan atau tidak melakukan perilaku yang sedang dipertimbangkan. Berdasarkan hasil studi, Subjective Norm yang berasal dari tim bisnis berpengaruh terhadap Intensi wiratani mahasiswa pertanian di Aceh.

Tim bisnis merupakan orang yang terlibat di dalam bisnis, saling mendukung dan bekerjasama untuk membangun suatu bisnis. Pola bisnis mahasiswa lebih banyak menggunakan kelompok untuk menyokong bisnisnya karena keterbatasan modal. Mayoritas responden memilih memiliki tim bisnis untuk memulai bisnisnya. Tim bisnis sangat berpengaruh terhadap indtensi wirausaha di sektor pertanian. Terbentuknya tim bisnis diinisiasi oleh seseorang untuk bersama-sama membangun bisnis dan mengharapkan keuntungan dalam bisnis. 
Sehingga visi misi bisnis dapat tercapai bila memiliki tim bisnis yang solid. Apabila mahasiswa mendapatkan tim bisnis yang baik, maka intensi berwiratani juga akan semakin tinggi.

\subsubsection{Subjective Norm yang berasal dari konsultan bisnis berpengaruh terhadap Intensi}

Subjectif norm persepsi atau pandangan seseorang terhadap kepercayaankepercayaan konsultan bisnis yang akan mempengaruhi niat untuk melakukan atau tidak melakukan perilaku yang sedang dipertimbangkan. Berdasarkan hasil studi, Subjective Norm yang berasal dari konsultan bisnis berpengaruh terhadap Intensi wiratani mahasiswa pertanian di Aceh.

Konsultan bisnis dalam hal ini banyak mahasiswa dapatkan dari dosen. Dosen memberikan konsultasi bisnis untuk mahasiwa. Hal ini dikarenakan mahasiswa menganggap dosen merupakan orang terdekt dilingkungan kampus yang dapat memberikan ilmu dalam berwirausaha. Harapan dosen terhadap karir wirausaha berpengaruh signiifikan terhadp intensi mahasiswa menjadi wirausaha tani.

Pola asuh kewirausahaan menentukan niat mahasiswa dalam berwirausaha. Kurikulum mengenai wirausaha yang baik dan sesuai dengan jamannya merupakan factor penting. K, Purwana, \& Wibowo, (2017) menyatakan bahwa hubungan yang signifikan antara pola asuh dan kurikulum kewirausahaan terhadap niat kewirausahaan mahasiswa. Sehingga kompetensi dosen berpengaruh signifikan terhadap jiwa kewirausahaan mahasiswa (Purwanto, 2015). Memotivasi peserta didik untuk lebih meningkatkan hasil belajarnya dan terutama dapat menerapkan sikap kewirausahaan kepada mahasiswa untuk menghasilkan generasi muda yang mampu bekerja secara mandiri (Stevani, 2016). Sehingga terciptanya wiratani sangat penting untuk keberlangsungan agribisnis di Indonesia.

\section{KESIMPULAN DAN SARAN}

\subsection{Kesimpulan}

Keseluruhan variable dari Subjective Norm memiliki pengaruh signifikan terhadap intensi mahasiswa pertanian dalam berwiratani. Subjective Norm yang berasal dari Orang tua, keluarga, tim bisnis, dan konsultan bisnis berpengaruh terhadap Intensi. Pandangan seseorang terhadap kepercayaan-kepercayaan orang tua, keluarga, tim bisnis, dan konsultan bisnis yang akan mempengaruhi niat untuk menjadi atau tidak menjadi wiratani.

\section{DAFTAR PUSTAKA}

Boateng, G. O., Polytechnic, T., Boateng, A. A., Polytechnic, C. C., \& Bampoe, H. S. (2014). BARRIERS TO YOUTHFUL ENTREPRENEURSHIP IN. Global Journal Of Business Research, 8(3), 109-120.

Candra, M. F., \& Sawitri, D. R. (2017). Kematangan Karir Pada Siswa Kelas Xi Smk Negeri 7 Semarang. Jurnal Empati, 6(Nomor 4), 112-118.

Islamadina, E. F., \& Yulianti, A. (2005). Persepsi Terhadap Dukungan Orangtua dan Kesulitan Pengambilan Keputusan Karir Pada Remaja Perceptions of Parental Support and Career Decision-Making Difficulties In Adolescents. Jurnal Psikologi, 12(1999), 33-38.

K, P. D., Purwana, D., \& Wibowo, A. (2017). Hubungan Pola Asuh, Kurikulum Kewirausahaan Dan Intensi Berwirausaha Mahasiswa Fakultas 
Ekonomi Universitas Negeri Jakarta. Jurnal Pendidikan Ekonomi Dan Bisnis, 5(1), 1-22.

Palos, R. (2016). The impact of family influence on the career choice of adolescents. Procedia Social and Behavioral Sciences, 2(1), 3407-3411. https://doi.org/10.1016/j.sbspro.2010.0 3.524

Panday, D. Santuy, R. (2015), "Identifying youth's difficulties to become agroentrepreneurs", National Youth Forum on Agro-based Entrepreneurship Development Lalitpur, January 9- 10, 2015

Pambudy, R., Burhanuddin, S.T., Budi, W., Kriswantriyono, A., and Satria, A. (2005), Bisnis dan Kewirausahaan dalam Sistem dan Usaha Agribisnis, Pustaka Wirausaha Muda, Bogor, ID.

Parcel, J. (2003), "Undergraduate perceptions of the need for an agricultural entrepreneurship curriculum", Selected Paper Prepared for Presentation at the Western Agricultural Economics Association Annual Meeting, Denver, June 13-16, 2003

Purwanto, M. I. (2015). Pengaruh Kompetensi Dosen dan Sikap Mahasiswa pada Mata Kuliah Kewirausahaan Terhadap Tumbuhnya Jiwa Enterpernuer Mahasiswa dalam
Penerapan Project Based Learning. Jurnal Probisnis, 8(2), 1-14.

Ridha, R. N., \& Wahyu, B. P. (2017). Entrepreneurship intention in agricultural sector of young generation in Indonesia. Asia Pacific Journal of Innovation and Entrepreneurship, 11(1), 76-89. https://doi.org/10.1108/apjie-04-2017022

Ryan, T.P. (1997). Modern Regression Analysis for Scientists and Engineers. Ghaitersburg: NIST

Setiabudi, kezia jade. (2019). Terhadap Niat Berwirausaha Mahasiswa Program Studi Manajemen Terakreditasi " A " Pada Perguruan Tinggi Swasta Di Kota Surabaya. AGORA, 7(1), 1-6.

Stevani, F. (2016). Pengaruh Pengembangan Kewirausahaan Mahasiswa Semester Viii Program Studi Pendidikan Ekonomi Ikip Pgri Bojonegoro. Magistra, 1(97), 111-118.

Susilaningsih. (1997). Pendidikan Kewirausahaan Di Perguruan Tinggi: Pentingkah Untuk Semua Profesi?. Jurnal Economia, 11(1), 1-9. 